\title{
Research on Multi - axis Machining of Titanium Alloy Integral Impeller
}

\author{
Guowei $L i^{1, *}$ \\ ${ }^{1}$ Haier School, Qingdao Technical College 369 Qiantangjiang Road, Huangdao District, Qingdao 266555 Shandong Province, \\ P.R.China
}

\begin{abstract}
Titanium alloy impeller is hard in material, with large curvature and complex shape, all these factors increase its manufacturing difficulty and machining cost. By formulating the corresponding process plan, the three-axis and five-axis NC machining are combined, and the phased processing mode is implemented. The cutting tools of different lengths are selected according to the needs, and the reasonable processing strategy and cutting parameters are selected. The experimental results show that the processing time of the titanium alloy impeller is reduced effectively, the cost of manufacturing is reduced, and the processing quality is improved.
\end{abstract}

\section{Introduction}

Aeroengine is the heart of aircraft, the main material used for integral impeller is usually titanium alloy with high hardness and strength. Because the thermal conductivity of titanium alloy is very small (only $1 / 5$ of iron and $1 / 14$ of aluminium), the cutting heat generated during cutting is not easy to dissipate, and it is concentrated in a small range near the cutting area and cutting edge, so the cutting temperature is very high, which will cause burning of the workpiece, softening of the tool material and accelerating tool wear. Therefore, titanium alloys are difficult to be machined in mechanical processing[1].

With the continuous improvement of engine performance, the shape of integral impeller becomes more complex. Its main characteristics are: thin blade, large twist, long blade and small blade spacing. From the point of view of processing technology, the existence of these characteristics poses a greater challenge for the mechanical processing of integral impellers[2]. Generally speaking, the machining difficulty of titanium alloy impeller is mainly as follows:

(1) The impeller hub is narrow, the blade is relatively long and thin, and the rigidity is low. Vibration and deformation are easy to occur in the process of machining, which makes the overall processing more difficult [3].

(2) The surface of impeller is free-form, and the blade is seriously distorted, which makes it easy to interfere and difficult to process[4].

(3) The impeller of this work is taken as an example: the diameter is $350 \mathrm{~mm}$, the length of the blade is $85 \mathrm{~mm}$, the narrowest hub of the hub is $12 \mathrm{~mm}$, the blade thickness is $2 \mathrm{~mm}$. Under the long condition of the cutting tool, the tool rigidity is poor and the cutter is easy to play the knife, while the cutting depth is controlled and the machining efficiency is difficult to be guaranteed.

(4) The chemical, physical and mechanical properties of titanium alloy make it particularly difficult to process. The material deformation coefficient is small and the cutting force per unit area is large. It is prone to bending deformation, causing vibration, increasing tool wear and affecting machining accuracy.

\section{Experimental Processing Parameters and Processing Conditions of Titanium Alloy Integral Impeller}

\subsection{Machining impeller parameters:}

The diameter of blade is $350 \mathrm{~mm}$, the length of blade is $85 \mathrm{~mm}$, the narrowest part of hub is $12 \mathrm{~mm}$, the thickness of blade is $2 \mathrm{~mm}$, the length of blade is $80-85 \mathrm{~mm}$, and the thickness of blade is $2 \mathrm{~mm}$.

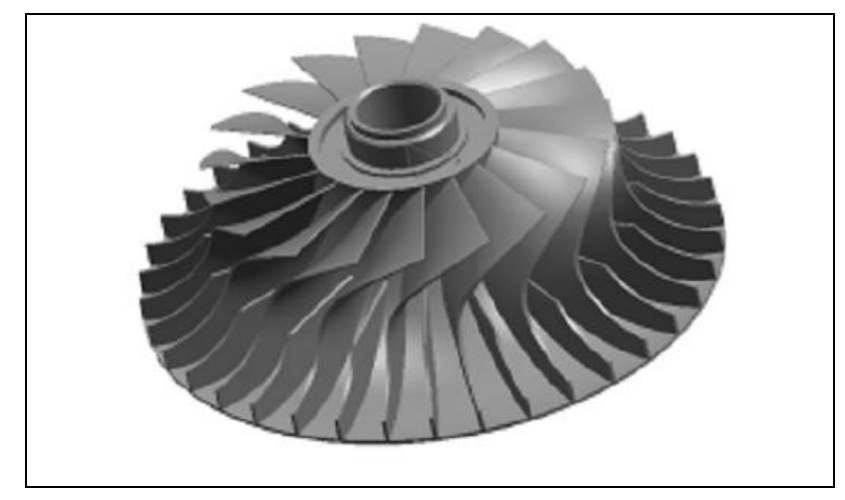

Fig. 1 integral impeller of titanium alloy

\footnotetext{
*Corresponding author: 326027869@qq.com
} 


\subsection{Experimental machine tool}

Three axis CNC machine tool: Vertical Machining Center for Heavy Cutting of Three-Axis All-Hard Rail -VB-715A - Taiwan You Jia machine tool

Five-axis linkage machine tool: DMG/DMU60

\subsection{Cutting Tools for Experiments}

Blade knife: D30R5

R angle knife: D12R1L120

Integral ball knife: D12R1L75; D12R1L100;

D12R1L120

\section{Efficient Machining Strategy and Method of Titanium Alloy Integral Impeller}

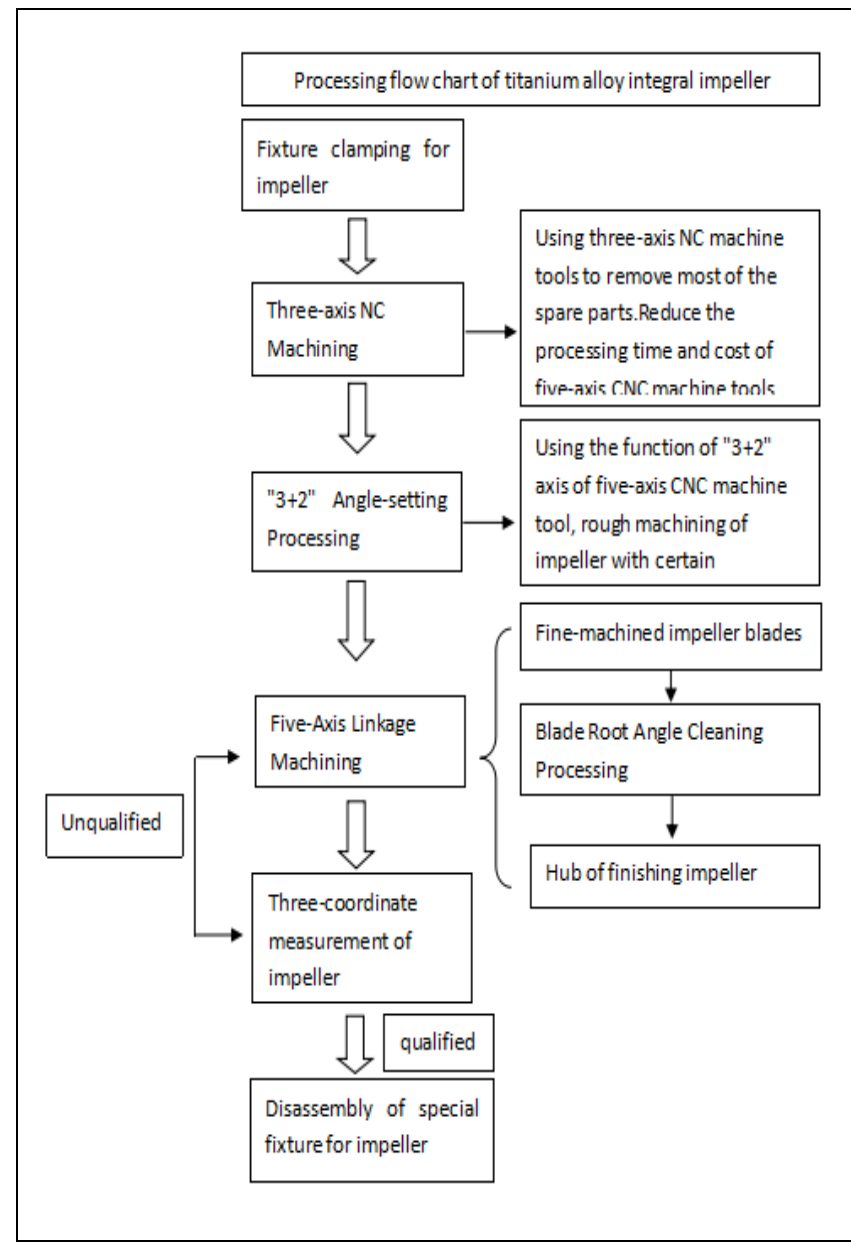

Fig. 2 Processing flow of titanium alloy integral impeller

Generally, the roughing of titanium alloy impeller in mechanical processing is large and time-consuming, and the NC processing technology is very complex. The conventional method of machining integral impeller is to use five-axis linkage $\mathrm{NC}$ machine tool and use special programming software to compile corresponding programs for its processing, which can be roughly divided into several steps: blade grooving, blade roughing, blade finishing, hub roughing and hub finishing. Using this conventional method, because the amount of impeller removal exceeds $90 \%$, roughing takes up a considerable length of processing time of five-axis machine tools, which is about $60 \%$ of the total processing time, so the processing efficiency is low and the processing cost is high.

In view of the shortcomings of the above process, an efficient processing flow of titanium alloy integral impeller is developed, as shown in Fig. 2. Tools and parameters used in processing experiments are shown in Table 1;

\subsection{Three-axis NC Machining}

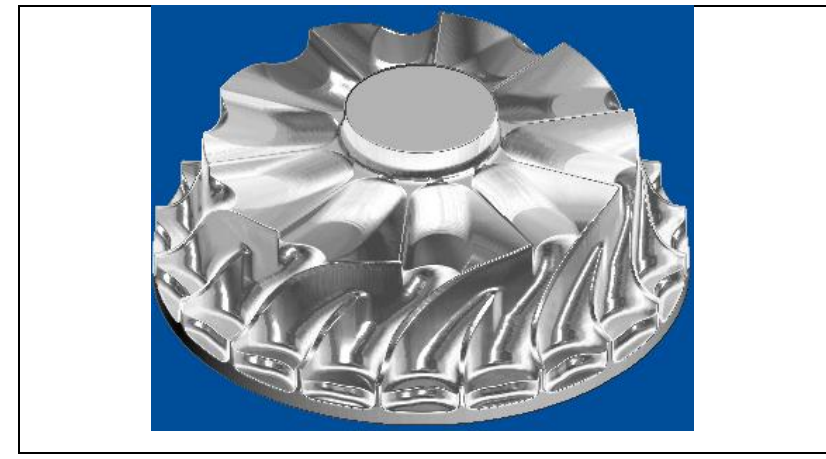

Fig. 3 machining effect of three axis NC machine tool Three-axis CNC machine tools are used to remove as many materials as possible (as shown in Fig. 3), which canreduce the processing time of five-axis $\mathrm{CNC}$ machine tools, and solve the problem of high processing cost and high processing cost of some five-axis CNC machine tools. Second, this processing method has good rigidity and high efficiency.

Table 1 Numerically Controlled Cutting Parameters of Titanium Alloy Integral Impeller

\begin{tabular}{|c|c|c|c|c}
\hline Cutting tool & $\begin{array}{c}\text { Spindle } \\
\text { speed/ } \\
(\mathrm{r} / \mathrm{min})\end{array}$ & $\begin{array}{c}\text { Cutting speed/ } \\
(\mathrm{mm} / \mathrm{min})\end{array}$ & $\begin{array}{c}\text { cutting } \\
\text { depth/ } \\
(\mathrm{mm})\end{array}$ & $\begin{array}{c}\text { Tool } \\
\text { spacing/ } \\
(\mathrm{mm})\end{array}$ \\
\hline $\begin{array}{c}\text { Diameter 30 } \\
\text { rounded } \\
\text { corner 5 blade } \\
\text { knife }\end{array}$ & 2000 & 2000 & 0.35 & 10 \\
\hline R6 ball cutter & 1500 & 800 & 1.2 & 3 \\
\hline R6 ball cutter & 1200 & 600 & 1.0 & 3 \\
\hline R6 ball cutter & 1200 & 600 & 0.8 & 3 \\
\hline R6 ball cutter & 6000 & 2500 & 0.35 & $\begin{array}{c}\text { Processing } \\
\text { in place }\end{array}$ \\
\hline R6 ball cutter & 1000 & 400 & $\begin{array}{c}\text { Processing } \\
\text { in place }\end{array}$ & $\begin{array}{c}\text { Processing } \\
\text { in place }\end{array}$ \\
\hline R6 ball cutter & 7500 & 3000 & $\begin{array}{c}\text { Processing } \\
\text { in place }\end{array}$ & 1 \\
\hline
\end{tabular}

Selection and improvement of processing strategy. On the basis of PowerMILL programming software, reasonable selection of processing strategy has a certain impact on processing quality and efficiency. In PowerMILL programming software, there are special strategies for processing impellers (as shown in Fig. 4) 


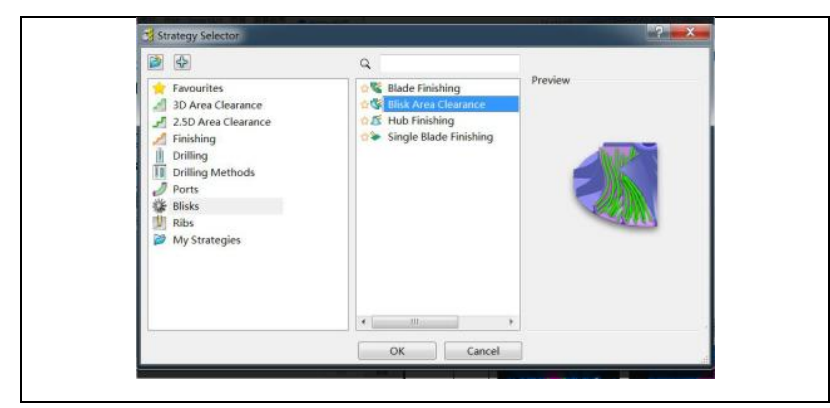

Fig. 4 impeller processing strategy of PowerMILL programming software

This processing strategy is very useful for machining impellers. Conventional processing usually only follows this strategy for NC machining of impellers. However, the experiment proves that if the impeller is processed according to this processing strategy, the effect is not ideal.

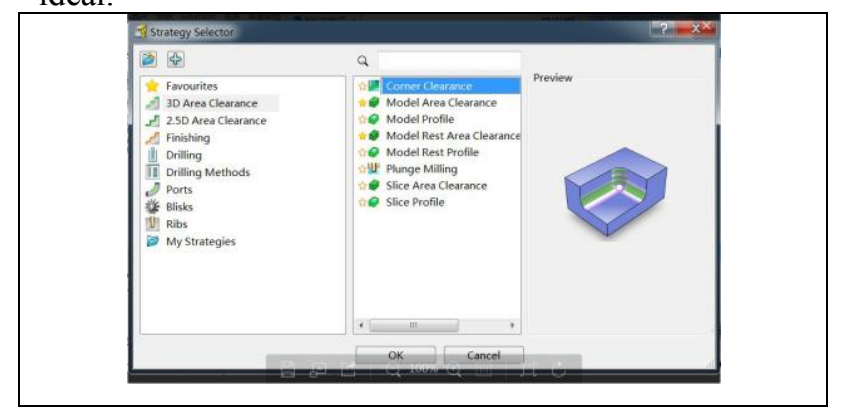

Fig. 5 offset area cleaning model

Therefore, it is necessary to improve the programming of titanium alloy impeller machining strategy. After improvement, the processing strategy of titanium alloy impeller is as follows: in three-axis $\mathrm{NC}$ machining and five-axis $\mathrm{NC}$ rough machining, the offset area clearance model (as shown in Fig. 5) is selected to process.

\section{2 "3 + 2" Fixed Angle Processing}

The principle of $3+2$ positioning processing is essentially the realization of three-axis function at a specific angle (i.e. "positioning"). Simply speaking, when the machine tool turns the angle, it is still processed in the way of ordinary three-axis.

Advantages of $3+2$ positioning processing: 1 ) Shorter and more rigid cutting tools can be used. 2) The tool can form a certain angle with the surface, and the spindle head can extend lower and be closer to the workpiece. 3) The tool moving distance is shorter and the program code is less.

When roughing five-axis $\mathrm{CNC}$ machine tools, try to avoid the swing of the rotating axis and use the " $3+2 "$ mode to fix the angle. The greater the swing amplitude of the rotating shaft, the worse the stability of the machine tool, the greater the vibration, the worse the tool wear, and the shorter the service life of the tool.

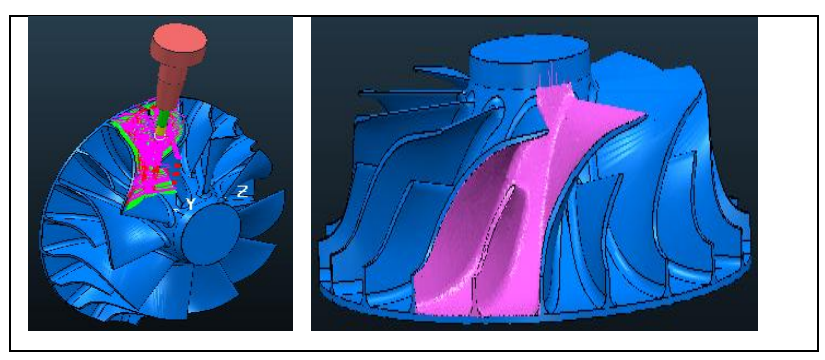

Fig. 6 angle machining effect of " $3+2 "$ axis

\subsection{Five-Axis Linkage Machining}

\subsubsection{Finish machining impeller blades}

The tool is gradually lengthened during processing. The longer the tool stretches out, the less rigid the tool is, and the cutter rebound phenomenon is easy to occur, which shortens the service life of the tool. Take the impeller as an example in Fig. 1. Firstly, the tool is extended $55 \mathrm{~mm}$ to remove most of the remaining material, secondly, the tool is extended $75 \mathrm{~mm}$ to remove some of the remaining material, and finally the tool is extended $80 \mathrm{~mm}$ to remove the remaining material. Because all machine tools now have tool storehouse, the tool is adjusted and loaded into the tool storehouse before processing, so it will not cause the waste of time to install the tool in the process of processing. The length of tool extension directly affects the selection of processing parameters, but it can greatly improve the processing efficiency.

\subsubsection{Blade Root Angle Cleaning Processing}

Because there is a large margin at the corner of the root when roughing, 3-5 knives are set aside at the bottom of the blade when finishing the blade. Because there is a large margin at the corner of the root when roughing, 3-5 cuts are allowed at the bottom of the blade when finishing the blade. After cleaning the roots and hard-to-process parts separately, the 3-5 cuts left in front are processed (the processing parameters used in the two kinds of processing are different, which will be described in detail below). This can reduce blade vibration, improve tool stability and reduce tool wear, but also can improve production efficiency.

\subsubsection{Finish Machining the Hub of Impeller}

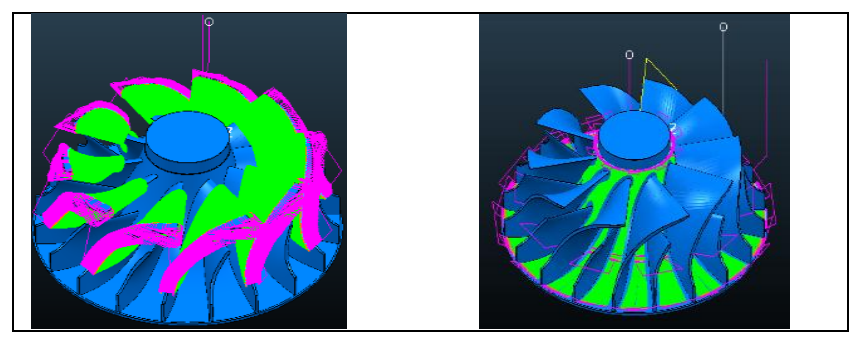

Fig. 7 blade finishing and hub finishing 
When finishing blades and hub on Five-axis NC machine

Table 2 Comparison of before and after process improvement

\begin{tabular}{|c|c|c|c|c|c|c|}
\hline \multicolumn{3}{|c|}{ Before process improvement } & \multicolumn{3}{|c|}{ After process improvement } & \multirow[b]{2}{*}{ Remarks } \\
\hline $\begin{array}{l}\text { Technological } \\
\text { process }\end{array}$ & time & $\begin{array}{l}\text { Total } \\
\text { working } \\
\text { hours }\end{array}$ & $\begin{array}{l}\text { Technological } \\
\text { process }\end{array}$ & time & $\begin{array}{l}\text { Total } \\
\text { working } \\
\text { hours }\end{array}$ & \\
\hline $\begin{array}{l}\text { Five-Axis NC Rough } \\
\text { Machining (Five-Axis } \\
\text { Linkage Machining) } \\
\end{array}$ & $\begin{array}{l}50 \text { hours } \\
35 \text { minutes }\end{array}$ & & $\begin{array}{l}\text { Three-axis } \quad \mathrm{NC} \\
\text { Machining }\end{array}$ & $\begin{array}{l}5 \text { hours } 30 \\
\text { minutes }\end{array}$ & \multirow{4}{*}{$\begin{array}{l}38 \text { hours } 1 \\
\text { minutes }\end{array}$} & $\begin{array}{l}\text { The data before the process } \\
\text { improvement are obtained from } \\
\text { repeated experiments provided by }\end{array}$ \\
\hline $\begin{array}{l}\text { Five-axis CNC } \\
\text { finishing blade }\end{array}$ & $\begin{array}{l}16 \text { hours } \\
19 \text { minutes }\end{array}$ & \begin{tabular}{ll}
\multicolumn{2}{c}{82} \\
hours & 50 \\
minutes &
\end{tabular} & $\begin{array}{ll}\text { Five-axis } & \mathrm{NC} \\
\text { Rough } & \\
\text { Machining } & \\
(" 3+2 " & \\
\text { Machining } & \\
\text { Mode) } & \\
\end{array}$ & $\begin{array}{l}13 \text { hours } 28 \\
\text { minutes }\end{array}$ & & $\begin{array}{l}\text { the enterprise after the process } \\
\text { improvement. } \\
\text { Because the characteristics of } \\
\text { tool life and processing strategy are } \\
\text { taken into account in the process of }\end{array}$ \\
\hline \multirow[t]{2}{*}{$\begin{array}{l}\text { Five-axis CNC } \\
\text { finishing hub }\end{array}$} & $\begin{array}{l}15 \text { hours } \\
56 \text { minutes }\end{array}$ & & $\begin{array}{l}\text { Five-axis } \mathrm{CNC} \\
\text { finishing blade }\end{array}$ & $\begin{array}{l}10 \text { hours } 21 \\
\text { minutes }\end{array}$ & & $\begin{array}{l}\text { machining, different processing } \\
\text { parameters are selected, which }\end{array}$ \\
\hline & & & $\begin{array}{l}\text { Five-axis } \mathrm{CNC} \\
\text { finishing hub }\end{array}$ & $\begin{array}{l}8 \text { hours } 42 \\
\text { minutes }\end{array}$ & & results in different processing time. \\
\hline
\end{tabular}

tools, the strategies of blade finishing and hub finishing are selected (as shown in Fig. 7).

\section{Analysis of Experimental Results}

\subsection{Titanium Alloy Whole Impeller Processing Process Improvement of the Whole Effect Analysis}

Compared with the previous processing methods, the improved processing technology of titanium alloy impeller has the following advantages:

Improve the processing efficiency of titanium alloy impeller

Reducing the processing cost of titanium alloy integral impeller

Improve the processing quality of titanium alloy integral impeller

\subsection{Analysis of Machining Efficiency}

Table 2 shows a comparison of the numerical control processing efficiency of a titanium alloy impeller before and after the process improvement as shown in Fig. 1.

From the above table, it can be clearly seen that the processing efficiency has been doubled by the process improvement: before the process improvement, it takes 80-85 hours to process a titanium alloy integral impeller as shown in Fig. 1, and 35-40 hours after the process improvement.

\subsection{Analysis of Processing Cost}

Increasing the processing efficiency blindly will often increase the cost of processing. Therefore, all factors are taken into account in the process improvement.

The following is a detailed analysis of the processing cost. Specific analysis data are as follows:

\subsubsection{Before Process Improvement}

The cutting parameters of high speed machining (high speed, large feed, less tool consumption) are used. The tool wear is serious. The cost of cutting tools used to process a titanium alloy integral impeller as shown in Fig. 1 is shown in Table 3 .

Table 3 Tool Cost Table for Process Improvement

\begin{tabular}{|l|l|c|c|l|l|}
\hline $\begin{array}{l}\text { Tool } \\
\text { type }\end{array}$ & $\begin{array}{l}\text { Tool } \\
\text { specifi } \\
\text { cation }\end{array}$ & $\begin{array}{l}\text { Cutting tool } \\
\text { price(yuan/ } \\
\text { Branch) }\end{array}$ & $\begin{array}{l}\text { Number of } \\
\text { cutters(Bra } \\
\text { nch) }\end{array}$ & $\begin{array}{l}\text { Total tool } \\
\text { price(yua } \\
\text { n) }\end{array}$ & $\begin{array}{l}\text { Total } \\
\text { (yuan } \\
\text { ) }\end{array}$ \\
\hline $\begin{array}{l}\text { R angle } \\
\text { knife }\end{array}$ & $\begin{array}{l}\text { D12R1 } \\
\text { L120 }\end{array}$ & 400 & 8 & 3200 & 4600 \\
\hline $\begin{array}{l}\text { Ball } \\
\text { nose } \\
\text { knife }\end{array}$ & $\begin{array}{l}\text { D12R6 } \\
\text { L120 }\end{array}$ & 350 & 4 & 1400 & 4600 \\
\hline
\end{tabular}

At present, the processing costs of various types of machine tools are as follows:

Three-axis CNC machine tool processing: 40 yuan/hour; five-axis CNC machine tool processing: 300 yuan/hour

It can be seen from Table 2 that the processing time of a titanium alloy impeller on a five-axis CNC machine tool is 81 hours.

The processing cost of the impeller can be calculated as

$300 * 81=24300$ yuan. It can be concluded that:

Processing cost $=$ processing cost + tool cost $=24300+$ $4600=28900$ yuan

\subsubsection{Process Improvement}

After process improvement, the cost of cutting tools used to process a titanium alloy impeller as shown in Fig. 1 is shown in Table 4. 
Table 4 Tool Cost Table after Process Improvement

\begin{tabular}{l|l|l|l|l|l}
\hline \multirow{2}{*}{$\begin{array}{l}\text { Tool } \\
\text { type }\end{array}$} & $\begin{array}{l}\text { Tool } \\
\text { specifi } \\
\text { cation }\end{array}$ & $\begin{array}{l}\text { Cutting tool } \\
\text { price(yuan/ } \\
\text { ranch) }\end{array}$ & $\begin{array}{l}\text { Number of } \\
\text { cutters(Bra } \\
\text { nch) }\end{array}$ & $\begin{array}{l}\text { Total tool } \\
\text { price } \\
\text { (yuan) }\end{array}$ & $\begin{array}{l}\text { Total } \\
\text { (yuan) }\end{array}$ \\
\hline $\begin{array}{l}\text { Blade } \\
\text { knife }\end{array}$ & D30R5 & $\begin{array}{l}30 \text { yuan / } \\
\text { slice }\end{array}$ & 2 slice & 60 & \\
\hline \multirow{4}{*}{$\begin{array}{l}\text { Ball } \\
\text { nose } \\
\text { knife }\end{array}$} & $\begin{array}{l}\text { D12R1 } \\
\text { L75 }\end{array}$ & 280 & 2 & 560 & \multirow{2}{*}{1960} \\
\cline { 2 - 5 } & $\begin{array}{l}\text { D12R1 } \\
\text { L100 }\end{array}$ & 320 & 2 & 640 & \\
\cline { 2 - 5 } & $\begin{array}{l}\text { D12R1 } \\
\text { L120 }\end{array}$ & 350 & 2 & 700 & \\
\hline
\end{tabular}

Note: All data in this table are obtained from repeated experiments of this project.

According to the machine tool time and processing cost provided above, combined with the actual processing time as shown in Table 4, it can be calculated that:

The processing cost of the impeller is $40 * 5.5+300$ *32 $=9820$ yuan, so the total processing cost is $9820+1960=11780$ yuan.

From the above series of calculation data, it can be seen that the process improvement not only shortens the processing time of titanium alloy impeller, but also greatly reduces the processing cost. Processing according to this scheme can increase production efficiency.

\subsection{Analysis of Measurement Data}

The impeller processed after process improvement is measured in three coordinates. From the data table of coordinate measurement, it can be seen that the machining accuracy of the titanium alloy impeller fully meets the processing requirements.

\section{Conclusion}

(1) The processing efficiency of impeller is improved effectively.

(2) The processing cost of impeller is greatly reduced.

(3) The strategy of efficient machining can be extended to other impeller processing.

\section{Acknowledgment}

This work was supported by the Shandong province vocational education skills inheritance and innovation platform

\section{References}

1. Pan Shixiao. Application of MIKRON HPM800U in Machining of Titanium Impeller[J]. Aeronautical Manufa-cturing Technology, 2011 13(019):85-87

2. GF Archisimir Group. Application of High performance Five-Axis Machining Center in Titanium Alloy Impeller Machining[J]. Defence Manufacturing Technology, 2011, 5(13): 18-19
3. Li guiwei, Dong Lei, Liu jukang.NC High efficiency Machining method of Titanium Alloy integral Impeller and its supporting fixture[P]. China Patents, ZL201510164212.8, 2015-04-08.

4. LIN Bingxiang. Multi axis machining technology of integral impeller based on Power Mill software[J]. World Nonferrous Metals, 2017, 13(13): 51-52 